\title{
Clinico-Physiological, Haemato-Biochemical and Urinalysis of 20 Adult Captive Indian Elephants (Elephas maximus)
}

\author{
M. Ranjini*, P. M. Deepa and R. U. Ashok \\ Department of Veterinary Epidemiology and Preventive Medicine, College of Veterinary and \\ Animal Sciences, Kerala Veterinary and Animal Sciences University, Pookode, Lakkidi PO- \\ 673 576, Wayanad, Kerala, India \\ *Corresponding author
}

\section{A B S T R A C T}

\section{Keywords}

Elephant, Physiology, Haematology, Serum biochemistry, Urinalysis

\section{Article Info}

\section{Accepted:}

17 January 2021

Available Online:

10 February 2021
Health is determined by biological, physiological and environmental variables. These variables differ for different species of animals. Species specific blood value reference intervals emphasising on variations associated with age, sex and geographical location are ideal for the proper diagnosis and treatment of a disease because species, age, sex, management, exercise and geographical location can all affect haematological values. The aim of this study was to establish a set of haematological, serum biochemical and urine chemistry reference values for captive Asian elephants of South India. Twenty apparently healthy adult captive Asian elephants (Elephas maximus) of either sex (10 male, 10 female) were selected at random for the study. Elephants that were neonates, pregnant, in lactation, in any disease condition and in musth were excluded. Selected elephants were subjected to clinical, physiological, haematological, serum biochemical and urine evaluation. The data acquired from the study were compared with universal standards in order to formulate baseline values. The results showed similarity in haematological, serum biochemical and urine parametrical values with that of previously published studies. There were significant difference in basophil count, band cell count, alanine aminotransferase and $\mathrm{pH}$ value (dipstick) between male and female group. The authors indicated that specific control conditions can be further incorporated to find the true values for the various parameters under observation.

\section{Introduction}

Elephants are the largest terrestrial animals alive today. These giant herbivores are considered to be a part of Indian tradition from the early age. Unfortunately, their population is declining due to habitat loss, poaching and increase in human population (Mikota and Kahn, 2000). In the conservation of these endangered species, veterinarians play a pivotal role by monitoring their health in captivity and in wild. Knowledge of the normal physiological, haematological, serum biochemical and urine parameters of elephants are useful in evaluating their health status as 
well as in monitoring the course of a disease or the response to a treatment. Reports on the normal parameters of elephants are few and reports on wild or free ranging elephants are even less common. This is due to the very few opportunities for collection of significant number of samples from captive, wild or free ranging animals. Elephant urine analysis is one of the less explored arena compared to haematology and serum biochemistry of elephants. Despite of the confirmation that elephants develop urinary tract infections, data regarding the same is very limited.

Urine collection and evaluation being least invasive technique, urine analysis holds a good potential and diagnostic value for monitoring of the general health of elephants. This article aims to establish baseline values for haematology, serum biochemistry and urine chemistry in clinically normal adult male and female elephants of South India.

\section{Materials and Methods}

Twenty apparently healthy adult captive Asian elephants (Elephas maximus) of either sex (10 male, 10 female) were selected for the study at random. Elephants which were neonates, pregnant, in lactation, in musth, in any apparent disease condition were exempted from the study. The selected animals were subjected to clinical, physiological, haematological, serum biochemical and urine evaluation.

Clinical and Physiological evaluation: Observations were made about the general appearance, behavioural habit, feeding habit and voiding habit (urine and dung) of the animals. Physiological parameters such as rectal temperature, pulse rate and respiratory rate were observed for a duration of one minute and recorded. Blood collection: Animals were placed in lateral recumbency. Blood was drawn from superficial marginal vein located at the external aspect of the ear using a clean, sterile 16-gauge disposable vacutainer needle into a sterile vacutainer tubes under aseptic conditions.

Haematology evaluation: Blood samples were collected in $2 \mathrm{ml}$ EDTA vacutainer tubes for the evaluation of haematological parameters (Orphee mythic 18vet - analyser) viz. haematocrit (HCT), haemoglobin (Hb), total erythrocyte count (TEC), mean corpuscular volume (MCV), mean corpuscular haemoglobin $(\mathrm{MCH})$, mean corpuscular haemoglobin concentration (MCHC), red cell distribution width (RDW), reticulocyte count, total leukocyte count (TLC), differential leukocyte count (DLC), platelet count (PC) and mean platelet count (MPC) on the day of presentation.

Serum biochemical evaluation: Blood samples were collected in $4 \mathrm{ml}$ serum vacutainer tube for the evaluation of serum biochemical parameters (Master T, Hospitex diagnostics, Italy) viz. blood urea nitrogen (BUN), serum creatinine, total bilirubin, direct bilirubin, indirect bilirubin, glucose, total protein, albumin, globulin, albumin globulin ratio, cholesterol, aspartate aminotransferase (AST), alanine aminotransferase (ALT), alkaline phosphatase (ALP) on the day of presentation.

Urine Collection: For ease of sample collection, urine samples were collected from elephants at dawn in the presence of mahout under sterile conditions. Mid-stream urine $(100 \mathrm{ml})$ was collected in sterile urine collection vial. Urinalysis: Urine was evaluated for colour, appearance, osmolality, mucous threads, $\mathrm{pH}$ (Cyberscan pH510 meter), protein (sulfosalicylic acid - SSA Test), and leukocytes, nitrite, urobilinogen, protein, $\mathrm{pH}$, blood, specific gravity, ketone, bilirubin, glucose using (Mission urine reagent strip from ACON LABS INC - dipstick).

Statistical analysis: The categorical variables 
were summarized in frequency (n) and percentage $(\%)$ and the continuous ones were expressed in mean and standard error (Mean \pm $\mathrm{SE}$ ). In order to compare quantitative variables in the groups, independent sample $t$ test for normally distributed variables and Mann Whitney $U$ test for non-parametric variables were performed. The association between urine colour, appearance and presence of mucus threads among different sex were assessed using the Chi square test and Fischer's exact test appropriately. The statistical analysis was carried out using IBM SPSS version 25.

\section{Results and Discussion}

The clinical examination (Table 1) was performed at the time of sample collection. All the animals included in the study were clinically normal and did not show any signs of systemic disorder or infection. All animals were healthy with good skin condition and normal pink mucous membranes. The animals were active and alert, with normal feed and water intake. There were no abnormalities detected in the frequency, colour and consistency of urination and defaecation. Physiological parameters like rectal temperature, pulse rate and respiration rate were collected on the day of presentation and evaluated. The values acquired where statistically analysed separately for male and female elephants. The mean, standard error of mean and t- test significance for the various parameters were tabulated (Table 2). The values obtained were compared with the previously published reports and found to be in accordance with (Buss and Wallner, 1965; Kock et al., 1993; Mikota, 2006). The variations observed were within normal range for the particular sex and age group.

Blood samples were collected for haematological and serum biochemical analysis on the day of presentation and evaluated. The values obtained were statistically analysed separately for male and female elephants. The mean and standard error of mean and t-test significance for the various parameters were tabulated (Table 3 and 4). The Haematocrit (HCT), Hb, RBC, MCV, $\mathrm{MCH}, \mathrm{MCHC}$, RDW, Platelet count values obtained for both male and female elephants were in agreement with the studies conducted by Brown and White, 1979; Salakij et al., 2005; Klinhom et al., 2017). In the present study, the bilobed monocytes were greater in number than the number of lymphocytes which was in accordance with the findings of Salakij et al., (2005). Reticulocytes were completely absent as observed previously by (Salakij et al., 2005; Klinhom et al., 2017). However, WBC count was found to be relatively high and this may be attributable to the variations arising from the different geographical locations where the elephants are held and subsequent variable management conditions (Klinhom et al., 2017). The number of eosinophils were more than monocytes as observed previously by (Salakij et al., 2005; Mel et al., 2014) but was found to be in contrast with the studies conducted by (Dastjerdi et al., 2016; Klinhom et al., 2017). Mild variations in the values may also be attributed to the different laboratory conditions, blood collection techniques and storage conditions. All the haematological parameters considered had no significance difference between the male and female group, except for basophils and band cells which showed significant difference between male and female group.

The BUN and total bilirubin value obtained were in agreement with the values reported by (Silva and Kuruwita, 1993; Allwin et al., 2015). The high total bilirubin values for elephants may be due the absence of gall bladder which leads to continuous secretion of bile from hepatic tissues. Creatinine values obtained were found to be in the upper limit of normal range obtained previously by other 
authors (Nirmalan and Nair, 1971; Fowler, 1986; Silva and Kuruwita, 1993). This variation may be influenced by the amount of creatinine generated by the skeletal muscles (Osborne et al., 1972). The serum glucose values can be inclined with respect to the age advancement and nutrition of the animal, overall mean of glucose values however was in accordance with previously published reports (Fowler, 1986; Mikota et al., 1994).

Brown and white, (1980) had opined that age advancement could be a probable reason for high serum protein and increase in globulin which could increase the viscosity of the blood. This can be a reason for the high protein values obtained in the present study, although the values lie within the previously reported acceptable range. Age, sex or musth has no effect on the $A / G$ ratio in Asian elephants as reported by (Pc, 1994).

The serum cholesterol values obtained are in agreement with those reported by Wallach and Boever (1983). The ALP, AST and ALT values obtained were found to be within the accepted reference range obtained in earlier studies (Mikota, 2006; Pandit et al., 2015).

Urine samples were collected on the day of presentation and evaluated. The values acquired where statistically analysed separately for male and female elephants. The mean and standard error of mean and t-test significance for the various parameters were tabulated (Table 5).

The appearance and colour of the urine were variable from straw coloured to dark yellow and from clear to cloudy. Turbidity or cloudiness in the urine is due to the presence of mucus cells and crystals in the urine (Benedict, 1936; Simon, 1958). Specific gravity values in the present study is in agreement with previous reports (Benedict et al., 1936; Wiedner et al., 2009). Healthy elephant kidney has negligible number of renal papillae and the contact between the urine and outer medulla at the calyx is limited, which suggests that elephant kidney has decreased ability to concentrate urine compared to other species (Schulte, 1937; Maluf, 1995). The osmolality values obtained in the present study was found in accordance with values obtained by (Wiedner et al., 2009). Wiedner et al., (2009) reported that the urine osmolality in elephants is considerably low when compared to other domesticated species.

The urinary $\mathrm{pH}$ of elephant is found to have inclination towards alkalinity like other herbivores (Benedict et al., 1936). The values obtained in $\mathrm{pH}$ meter and dipstick was found to be in the alkaline range and there was no significant difference noted between $\mathrm{pH}$ values in $\mathrm{pH}$ meter and dipstick as observed using t- test, which was found in accordance with previous report (Wiedner et al., 2009). Presence of glucose, ketone, leukocytes, blood and protein is nil to negligible.

Protein evaluated using sulfosalicylic acid SSA test and dipstick showed similar values. Urobilinogen and bilirubin values were observed in traces. Osborne et al., (1999)in his study found that minor amounts of bilirubin can be a normal finding in healthy elephants. The variations observed in serum biochemical values were within normal range for the particular sex and age group.

Health is determined by biological, physiological and environmental variables. These variables differ for different species of animals. Since haematology, serum biochemistry and urinalysis parameters has the potential to indicate the physiology of the body, these values can be used for assessing the health of the animals. 
Table.1 Observations on clinical examination of the animals

\begin{tabular}{|c|c|c|c|c|}
\hline \multirow[t]{2}{*}{ Sl. No. } & \multirow[t]{2}{*}{ Parameter } & \multirow[t]{2}{*}{ Unit } & \multicolumn{2}{|c|}{ Observation } \\
\hline & & & Male & Female \\
\hline 1 & General Appearance & $\begin{array}{l}\text { Obese, Normal, } \\
\text { Emaciated }\end{array}$ & Normal & Normal \\
\hline 2 & Behavioural Habit & $\begin{array}{l}\text { Active, Dullness, } \\
\text { Abnormal behaviour }\end{array}$ & Active, Alert & Active, Alert \\
\hline 3 & Feeding Habit & $\begin{array}{c}\text { Frequency, Quantity, } \\
\text { Duration }\end{array}$ & $\begin{array}{c}\text { No } \\
\text { Abnormalities } \\
\text { Detected }\end{array}$ & $\begin{array}{c}\text { No } \\
\text { Abnormalities } \\
\text { Detected }\end{array}$ \\
\hline 4 & Water Intake & $\begin{array}{c}\text { Frequency, Quantity, } \\
\text { Duration }\end{array}$ & $\begin{array}{c}\text { No } \\
\text { Abnormalities } \\
\text { Detected }\end{array}$ & $\begin{array}{c}\text { No } \\
\text { Abnormalities } \\
\text { Detected }\end{array}$ \\
\hline 5 & Dung Voiding Habit & $\begin{array}{c}\text { Frequency, Quantity, } \\
\text { Consistency, Colour, } \\
\text { Smell }\end{array}$ & $\begin{array}{c}\text { No } \\
\text { Abnormalities } \\
\text { Detected }\end{array}$ & $\begin{array}{c}\text { No } \\
\text { Abnormalities } \\
\text { Detected }\end{array}$ \\
\hline 6 & Urine Voiding Habit & $\begin{array}{c}\text { Frequency, } \\
\text { Duration, Quantity, } \\
\text { Flow, Colour, Smell }\end{array}$ & $\begin{array}{c}\text { No } \\
\text { Abnormalities } \\
\text { Detected }\end{array}$ & $\begin{array}{c}\text { No } \\
\text { Abnormalities } \\
\text { Detected }\end{array}$ \\
\hline
\end{tabular}

Table.2 Observations on physiological parameters

\begin{tabular}{|c|c|c|c|c|}
\hline Sl. No. & Parameter & \multirow{2}{*}{ Unit } & \multicolumn{2}{|c|}{ Observation } \\
\cline { 4 - 5 } & & & Male & Female \\
\hline $\mathbf{1}$ & Rectal Temperature & ${ }^{\circ} \mathrm{F}$ & $96.65 \pm 0.07$ & $96.89 \pm 0.06$ \\
\hline $\mathbf{2}$ & Pulse rate & Pulse/min & $30.90 \pm 1.19$ & $29.80 \pm 0.85$ \\
\hline $\mathbf{3}$ & Respiratory rate & Breath/min & $5.1 \pm 0.27$ & $4.9 \pm 0.27$ \\
\hline
\end{tabular}


Table.3 Observations on haematological parameters

\begin{tabular}{|c|c|c|c|c|c|}
\hline \multirow{2}{*}{$\begin{array}{l}\text { Sl. } \\
\text { No. }\end{array}$} & \multirow[t]{2}{*}{ Parameters } & \multirow[t]{2}{*}{ Unit } & \multicolumn{2}{|c|}{ Observation } & \multirow[b]{2}{*}{ P value } \\
\hline & & & Male & Female & \\
\hline 1 & Haematocrit & $\%$ & $31.07 \pm 0.81$ & $30.29 \pm 0.53$ & 0.44 \\
\hline 2 & Haemoglobin & $\mathrm{g} / \mathrm{dL}$ & $10.92 \pm 0.42$ & $11.01 \pm 0.42$ & 0.88 \\
\hline 3 & Total Erythrocyte Count & $10^{12} / \mathrm{L}$ & $02.62 \pm 0.08$ & $02.37 \pm 0.08$ & 0.66 \\
\hline 4 & $\begin{array}{l}\text { Mean Corpuscular } \\
\text { Volume }\end{array}$ & $\mathrm{fL}$ & $119.51 \pm 5.14$ & $129.03 \pm 5.20$ & 0.21 \\
\hline 5 & $\begin{array}{l}\text { Mean Corpuscular } \\
\text { Haemoglobin }\end{array}$ & $\mathrm{pg}$ & $41.94 \pm 1.85$ & $46.64 \pm 1.78$ & 0.08 \\
\hline 6 & $\begin{array}{l}\text { Mean Corpuscular } \\
\text { Haemoglobin } \\
\text { Concentration }\end{array}$ & $\mathrm{g} / \mathrm{dL}$ & $35.52 \pm 1.98$ & $36.63 \pm 1.92$ & 0.69 \\
\hline 7 & $\begin{array}{l}\text { Red Cell Distribution } \\
\text { Width }\end{array}$ & $\%$ & $14.98 \pm 0.19$ & $15.18 \pm 0.25$ & 0.54 \\
\hline 8 & Reticulocyte & $\%$ & $00.00 \pm 0.00$ & $00.00 \pm 0.00$ & 0.00 \\
\hline 9 & Total Leukocyte Count & $10^{9} / \mathrm{L}$ & $17.61 \pm 0.21$ & $17.20 \pm 0.27$ & 0.26 \\
\hline 10 & Bands & $10^{9} / \mathrm{L}$ & $0.047 \pm 0.008$ & $0.075 \pm 0.008$ & 0.03 \\
\hline 11 & Neutrophils & $10^{9} / \mathrm{L}$ & $05.38 \pm 0.25$ & $04.97 \pm 0.13$ & 0.18 \\
\hline 12 & Eosinophils & $10^{9} / \mathrm{L}$ & $00.47 \pm 0.10$ & $00.69 \pm 0.07$ & 0.12 \\
\hline 13 & Basophils & $10^{9} / \mathrm{L}$ & $0.065 \pm 0.006$ & $0.033 \pm 0.008$ & $0.01^{*}$ \\
\hline 14 & Lymphocytes & $10^{9} / \mathrm{L}$ & $04.96 \pm 0.31$ & $05.06 \pm 0.36$ & 0.84 \\
\hline 15 & Bilobed Monocytes & $10^{9} / \mathrm{L}$ & $06.30 \pm 0.12$ & $06.02 \pm 0.17$ & 0.22 \\
\hline 16 & Monocytes & $10^{9} / \mathrm{L}$ & $00.41 \pm 0.10$ & $00.34 \pm 0.07$ & 0.20 \\
\hline 17 & Bands & $\%$ & $00.26 \pm 0.04$ & $00.43 \pm 0.05$ & $0.03^{*}$ \\
\hline 18 & Neutrophils & $\%$ & $30.55 \pm 1.35$ & $28.93 \pm 0.68$ & 0.31 \\
\hline 19 & Eosinophils & $\%$ & $02.72 \pm 0.58$ & $03.97 \pm 0.42$ & 0.10 \\
\hline 20 & Basophils & $\%$ & $00.36 \pm 0.038$ & $00.18 \pm 0.04$ & $0.01 *$ \\
\hline 21 & Lymphocytes & $\%$ & $28.15 \pm 1.72$ & $29.29 \pm 1.79$ & 0.65 \\
\hline 22 & Bilobed Monocytes & $\%$ & $35.81 \pm 0.80$ & $35.16 \pm 1.32$ & 0.22 \\
\hline 23 & Monocytes & $\%$ & $03.48 \pm 0.58$ & $02.00 \pm 0.46$ & 0.20 \\
\hline 24 & Platelet Count & $10^{11} / \mathrm{L}$ & $03.48 \pm 0.06$ & $03.46 \pm 0.11$ & 0.90 \\
\hline 25 & Mean Platelet Volume & $\mathrm{fL}$ & $04.47 \pm 0.08$ & $04.66 \pm 0.09$ & 0.16 \\
\hline
\end{tabular}

N.B: P value derived from independent t-test; * indicates significant difference; Bands and basophil 
Table.4 Observations on serum biochemical parameters

\begin{tabular}{|c|c|c|c|c|c|}
\hline \multirow{2}{*}{ Sl. No. } & Parameters & \multirow{2}{*}{ Unit } & \multicolumn{2}{|c|}{ Observation } & \\
\cline { 4 - 6 } & & & Male & Female & P value \\
\hline $\mathbf{1}$ & Blood Urea Nitrogen & $\mathrm{mg} / \mathrm{dL}$ & $15.59 \pm 0.21$ & $15.71 \pm 0.24$ & 0.70 \\
\hline $\mathbf{2}$ & Creatinine & $\mathrm{mg} / \mathrm{dL}$ & $01.64 \pm 0.09$ & $01.41 \pm 0.11$ & 0.13 \\
\hline $\mathbf{3}$ & Total Bilirubin & $\mathrm{mg} / \mathrm{dL}$ & $00.72 \pm 0.02$ & $00.71 \pm 0.02$ & 0.66 \\
\hline $\mathbf{4}$ & Direct Bilirubin & $\mathrm{mg} / \mathrm{dL}$ & $00.62 \pm 0.01$ & $00.60 \pm 0.02$ & 0.49 \\
\hline $\mathbf{5}$ & Indirect Bilirubin & $\mathrm{mg} / \mathrm{dL}$ & $0.103 \pm 0.015$ & $0.108 \pm 0.009$ & 0.35 \\
\hline $\mathbf{6}$ & Glucose & $\mathrm{mg} / \mathrm{dL}$ & $79.69 \pm 0.64$ & $79.96 \pm 0.74$ & 0.79 \\
\hline $\mathbf{7}$ & Total Protein & $\mathrm{g} / \mathrm{dL}$ & $07.07 \pm 0.13$ & $07.08 \pm 0.13$ & 0.94 \\
\hline $\mathbf{8}$ & Albumin & $\mathrm{g} / \mathrm{dL}$ & $02.51 \pm 0.10$ & $02.56 \pm 0.08$ & 0.73 \\
\hline $\mathbf{9}$ & Globulin & $\mathrm{g} / \mathrm{dL}$ & $04.55 \pm 0.07$ & $04.52 \pm 0.09$ & 0.80 \\
\hline $\mathbf{1 0}$ & A/G Ratio & - & $00.54 \pm 0.02$ & $00.56 \pm 0.02$ & 0.66 \\
\hline $\mathbf{1 1}$ & Cholesterol & $\mathrm{mg} / \mathrm{dL}$ & $58.38 \pm 1.16$ & $59.06 \pm 1.16$ & 0.67 \\
\hline $\mathbf{1 2}$ & Aspartate Aminotransferase & $\mathrm{IU} / \mathrm{L}$ & $30.20 \pm 2.05$ & $28.20 \pm 2.15$ & 0.51 \\
\hline $\mathbf{1 3}$ & Alanine Aminotransferase & $\mathrm{IU} / \mathrm{L}$ & $03.17 \pm 0.17$ & $02.49 \pm 0.21$ & $0.03 *$ \\
\hline $\mathbf{1 4}$ & Alkaline Phosphatase & $\mathrm{IU} / \mathrm{L}$ & $276.0 \pm 32.96$ & $247.3 \pm 24.70$ & 0.36 \\
\hline
\end{tabular}

N.B: P value derived from independent t-test; * indicates significant difference in ALT value

Table.5 Observations on urine analysis

\begin{tabular}{|c|c|c|c|c|c|}
\hline \multirow{2}{*}{$\begin{array}{l}\text { Sl. } \\
\text { No. }\end{array}$} & \multirow[t]{2}{*}{ Parameters } & \multirow[t]{2}{*}{ Unit } & \multicolumn{2}{|c|}{ Observation } & \multirow[b]{2}{*}{ P value } \\
\hline & & & Males & Females & \\
\hline \multirow[t]{2}{*}{1} & \multirow[t]{2}{*}{ Colour } & Deep Yellow & $20 \%$ & $50 \%$ & \multirow[t]{2}{*}{0.16} \\
\hline & & Straw Yellow & $80 \%$ & $50 \%$ & \\
\hline \multirow[t]{2}{*}{2} & \multirow[t]{2}{*}{ Appearance } & Clear Urine & $80 \%$ & $40 \%$ & \multirow[t]{2}{*}{0.07} \\
\hline & & Cloudy Urine & $20 \%$ & $60 \%$ & \\
\hline 3 & Osmolality & $\mathrm{mOsm} / \mathrm{kg}$ & $628.04 \pm 0.40$ & $517.15 \pm 1.70$ & 0.11 \\
\hline \multirow[t]{2}{*}{4} & \multirow[t]{2}{*}{ Mucous Threads } & Positive & $0 \%$ & $20 \%$ & \multirow[t]{2}{*}{0.14} \\
\hline & & Negative & $100 \%$ & $80 \%$ & \\
\hline 5 & $\mathrm{pH}$ Meter & - & $6.81 \pm 0.19$ & $7.53 \pm 0.27$ & 0.05 \\
\hline \multirow[t]{2}{*}{6} & \multirow{2}{*}{$\begin{array}{l}\text { Protein (Sulfosalicylic } \\
\text { Acid) }\end{array}$} & Positive & $0 \%$ & $0 \%$ & - \\
\hline & & Negative & $100 \%$ & $100 \%$ & - \\
\hline 7 & Leukocytes (Dipstick) & Leu/ $\mu \mathrm{L}$ & $15 \pm$ & $15 \pm$ & - \\
\hline \multirow[t]{2}{*}{8} & \multirow[t]{2}{*}{ Nitrite (Dipstick) } & Positive & $50 \%$ & $100 \%$ & - \\
\hline & & Negative & $50 \%$ & $0 \%$ & - \\
\hline 9 & Urobilinogen (Dipstick) & $\mathrm{mg} / \mathrm{dL}$ & $0.20 \pm 18$ & $0.20 \pm 18$ & 1.00 \\
\hline 10 & Protein (Dipstick) & $\mathrm{mg} / \mathrm{dL}$ & $0.00 \pm 0.00$ & $0.00 \pm 0.00$ & 0.00 \\
\hline 11 & pH (Dipstick) & - & $6.85 \pm 0.18$ & $7.55 \pm 0.26$ & $0.04 *$ \\
\hline 12 & Blood (Dipstick) & Ery $/ \mu \mathrm{L}$ & $0.00 \pm 0.00$ & $0.00 \pm 0.00$ & 0.00 \\
\hline 13 & Specific Gravity (Dipstick) & - & $1.016 \pm 0.016$ & $1.018 \pm 0.018$ & 0.30 \\
\hline 14 & Ketone (Dipstick) & $\mathrm{mg} / \mathrm{dL}$ & $0.00 \pm 0.00$ & $0.00 \pm 0.00$ & 0.00 \\
\hline 15 & Bilirubin (Dipstick) & $\mathrm{mg} / \mathrm{dL}$ & $0.10 \pm 0.10$ & $0.00 \pm 0.00$ & 0.00 \\
\hline 16 & Glucose (Dipstick) & $\mathrm{mg} / \mathrm{dL}$ & $0.00 \pm 0.00$ & $0.00 \pm 0.00$ & 0.00 \\
\hline
\end{tabular}

N.B: P value derived from independent $\mathrm{t}$-test; $*$ indicates significant difference in $\mathrm{pH}$ dipstick value 
The present study aims to furnish insight the physiological, haematological, serum biochemical and urine evaluation of normal adult captive Indian elephants (Elephas maximus) of South India with an objective to improve the preventive health care system of elephants. There were significant difference in basophil count, band cell count, alanine aminotransferase and $\mathrm{pH}$ value (dipstick) between male and female group. The authors indicated that specific control conditions like uniform age group, location, physical activity, feeding and watering habits can be further incorporated to find the true values for the various parameters under observation. Evaluation and understanding of these parameters can greatly contribute to early diagnosis of disease process and improve quality of treatment provided.

\section{Acknowledgement}

The authors are thankful to the Dean, College of Veterinary and Animal Sciences (CVAS) for providing the facility for the conduct of present study.

\section{References}

Allwin, B., Kalalgnan, P., Kumar, G., Senthil,N., Vairamuthu, S., and Kalyaan, U. 2015. Haematology of the asian elephants. Adv. Multidis Aplinari Res, 2(3), 82-86.

Benedict, F. G.1936. The physiology of the elephant. The physiology of the elephant.

Brown, I. R. F. and White, P. T.1979. Serum electrolytes, lipids and cortisol in the African elephant, Loxodonta africana. Comparative Biochemistry and Physiology Part A: Physiology, 62(4), 899-901.

Buss, I. O. and Wallner, A.1965. Body temperature of the African elephant. Journal of Mammalogy, 46(1), 104-
107.

Dastjerdi, A., Seilern-Moy, Karin D., Falko, S., and Fieki, M. 2016. Surviving and fatal elephant endotheliotropic herpesvirus-1A infections in juvenile Asian elephants-lessons learned and recommendations on anti-herpesviral therapy. BMC veterinary research, 12(1), 178.

Fowler, M. E.1986. Elephants (Proboscidae). Zoo and Wild Animal Medicine, 884923.

Klinhom, S., Loythong, J. and Thitaram, C.2017. Hematologic and biochemical reference intervals for captive Asian elephants (Elephas maximus) in Thailand. Kafkas Univ Vet Fak Derg, 23(4), 665-668.

Kock, R. A., Morkel, P. and Kock, M. D.1993. Current immobilization procedures used in elephants. Zoo and Wild Animal Medicine, 3rd Edition. California, USA.

Maluf, N. S. R.1995. Kidney of elephants. The Anatomical Record, 242(4), 491-514.

Mel, R. K. D., Ratnasooriya, W., and Dangolla,A.2014. A comparative haematological analysis of Asian Elephants Elephas maximus Linnaeus 1758 (Mammalia: Proboscidea: Elephantidae) managed under different captive conditions in Sri Lanka. Journal of Threatened Taxa, 6(8), 6148-6150.

Mikota, S. K.2006. Preventive health care and physical examination. Biology, medicine, and surgery of elephants, 67-73.

Mikota, S. K. and Kahn, M. J. 2000. Hematology of the elephant. Schalm's Veterinary Hematology. 5thed. Lippincott William and Wilkins, Philadelphia, 1191-1995.

Mikota, S. K., Sargent, E. L. and Ranglack, G. S.1994. Medical management of the elephant. Indira Publishing House. 
Nirmalan, G. and Nair, S. G. 1971. Plasma proteins and certain non-protein nitrogenous constituents in the blood of Indian elephants (Elephas maximus). British Veterinary Journal, 127(5), 207-213.

Osborne, C. A., Low, D. G. and Finco, D. R. 1972. Canine and feline urology.

Pc, S. 1994. Monitoring And Managing The Musth In Asian Elephants. Livestock Production and Management; Chennai.

Salakij, J., Chaleow, S., Nual- Anong, N., Suntaree, A., and Piyawan 2005. Hematology, cytochemistry and ultrastructure of blood cells from Asian elephant (Elephas maximus). Agriculture and Natural Resources, 39(3), 482-493.
Schulte, T. L. 1937. The genito- urinary system of the Elephas indicus male. American Journal of Anatomy, 61(1), 131-157.

Silva, I. D. and Kuruwita, V. Y. 1993. Hematology, plasma, and serum biochemistry values in free-ranging elephants (Elephas maximus ceylonicus) in Sri Lanka. Journal of zoo and wildlife medicine, 434-439.

Simon, K. J. 1958. A preliminary study of the urine of elephants. Indian Vet. J, 35, 345-348.

Wiedner, E., Alleman, A. R. and Isaza, R. 2009. Urinalysis in Asian elephants (Elephas maximus). Journal of Zoo and Wildlife Medicine, 40(4), 659-666.

\section{How to cite this article:}

Ranjini, M., P. M. Deepa and Ashok, R. U. 2021. Clinico-Physiological, HaematoBiochemical and Urinalysis of 20 Adult Captive Indian Elephants (Elephas maximus). Int.J.Curr.Microbiol.App.Sci. 10(02): 2091-2099. doi: https://doi.org/10.20546/ijcmas.2021.1002.249 